\title{
Pelatihan Pembuatan Bahan Bakar Minyak Nyamplung (Calophyllum inophyllum) bagi Masyarakat Banyuwangi Jawa Timur
}

\section{Muh. Nurkoyim Kustanto*1, Nasrul Ilminnafik², Mahros Darsin³, Imam Rudi Sugara4, Deny Tomy Andrianto5 ${ }^{5}$ Ahmad Iqbal Fawaid 6}

\author{
1,2,3,6 Teknik Mesin, Fakultas Teknik, Universitas Jember, Indonesia \\ 4,5Magister Teknik Mesin, Fakultas Teknik, Universitas Jember, Indonesia \\ *e-mail: nasrul.teknik@unej.ac.id²
}

\begin{abstract}
Abstrak
Seiring kenaikan konsumsi energi minyak dan menurunnya cadangan minyak bumi, maka perlu beralih ke minyak nabati sebagai sumber bahan bakar terbarukan, salah satunya adalah dari biji nyamplung. Biji nyamplung banyak terdapat di desa Kebondalem, Kecamatan Bangorejo, Kabupaten Banyuwangi. Pengabdian masyarakat ini bertujuan mengenalkan potensi minyak nyamplung ke masyarakat desa tersebut. Kegiatan pengabdian dilakukan oleh tim gabungan dosen dan mahasiswa jurusan Mesin, Fakultas Teknik, Universitas Jember. Kegiatan berupa pengenalan potensi biji nyamplung untuk alternative bahan bakar, dilanjutakn dengan peragaan pengepresan biji menjadi minyak. Di sela-sela kedua acara teresbut diselingi tanya jawab dan diskusi. Hasil dari pengabdian ini cukup membuka wawasan warga desa yang hadir akan potensi nyamplung yang selama ini terabaikan. Tokoh masyarakat dan karang taruna siap untuk menindaklanjuti kegiatan ini dengan rencana penanaman lahan hutan desa dengan nyamplung. Perlu arahan dan kegiatan lanjutan untuk menyambut antusiasme warga desa ini.
\end{abstract}

Kata kunci: Bahan Bakar Bio, Energi Terbarukan, Minyak Biji Nyamplung

\section{Abstract}

As oil energy consumption increases and petroleum reserves decrease, it is necessary to switch to vegetable oil as a renewable fuel source, one of which is from nyamplung seeds. Nyamplung seeds are widely available in the village of Kebondalem, Bangorejo District, Banyuwangi Regency. This community service aims to introduce the potential of nyamplung oil to the village community. Service activities were carried out by a joint team of lecturers and students of Mechanical Engineering Deaprtment, Faculty of Engineering, University of Jember. Activities in the form of introducing the potential of nyamplung seeds for alternative fuels, followed by demonstrations of pressing seeds into oil. On the sidelines of the two events, questions and answers were interspersed with discussions. The results of this service are enough to open up the insight of the villagers who are present on the potential of nyamplung which has been neglected so far. Community leaders and youth organizations are ready to follow up this activity with plans to plant village forest land with nyamplung. Further direction and activities are needed to welcome the enthusiasm of the villagers.

Keywords: Calophyllum inophyllum Seed Oil, Biofuel, Renewable Energy

\section{PENDAHULUAN}

Kecamatan Bangorejo berada di bagian selatan Kabupaten Banyuwangi, dengan luas luas 137,43 km². Jumlah penduduknya 65709 jiwa (Banyuwangi, 2017), tersebar di 7 Desa. Berdasarkan tipe potensi desa, sebagian besar desa tersebut merupakan desa penghasil pertanian mulai dari padi, sayuran, buah-buahan, palawija, serta perkebunan.

Di Kecamatan Bangorejo terdapat beberapa desa yang mempunyai banyak pohon nyamplung (Chalophyllum inophyllum). Pohon nyamplung tumbuh secara liar tanpa pemeliharaan yang rumit, bahkan cenderung tidak mendapatkan perhatian karena masyarakat setempat tidak memahami nilai ekonomisnya.

Jenis pohon nyamplung merupakan tanaman hutan serbaguna yang salah satu manfaatnya sebagai bahan baku energi (biofuel) dari produk buahnya (biji nyamplung) sehingga jenis ini dikelompokkan sebagai HHBK penghasil minyak lemak, pati, dan buah-buahan $(B u K U$ Pe G a N G a N, n.d.). Pohon nyamplung termasuk jenis pohon yang mempunyai banyak manfaat. Beberapa keunggulannya ditinjau dari prospek pemanfaatannya adalah regenerasi tanaman 
nyamplung mudah dan berbuah sepanjang tahun, tahan terhadap lingkungan ekstrem, relatif mudah dibudidayakan, hampir seluruh bagian tanaman berdayaguna dan menghasilkan berbagai macam produk yang memiliki nilai ekonomis; tanaman dapat berfungsi sebagai pemecah angin (wind breaker) untuk tanaman pertanian dan konservasi sempadan pantai, serta pemanfaatan untuk bahan baku energi atau bahan bakar nabati (BBN). Kelebihan lain nyamplung sebagai bahan baku BBN adalah kandungan minyak dari bijinya sangat tinggi dan dalam pemanfaatannya tidak berkompetisi dengan kepentingan pangan. Selama ini biji nyamplung tidak banyak dimanfaatkan oleh masyarakat bahkan tidak mengetahui jika biji nyamplung bisa dimanfaatkan dan diproses menjadi bahan bakar.

Sejumlah penelitian telah dilakukan untuk membuat minyak dari biji nyamplung. Minyak nyamplung bisa diproses lebih lanjut menjadi biodiesel. Pembuatan minyak nyamplung sudah dikembangkan dengan beberapa metode. Sany dkk (2015) membuat minyak nyamplung dengan ekstraksi liquid-liquid (Industri, 2015). Peneliti lain membuat biodiesel nyamplung dengan beberapa macam katalis (Araujo, 2017). Dari penelitian-penelitian tersebut diperoleh bahwa nyamplung memiliki peluang sebagai salah satu potensi yang bisa dikembangkan sebagai bahan bakar alternatif yang bisa dikembangkan oleh masyarakat secara luas. Selain sebagai bahan bakar, nyamplung juga mempunyai multifungsi (Susila, 2018), diantaranya untuk digunakan untuk bahan baku sabun padat transparan (Handayani et al., 2020), body lotion (Rakhmawati et al., 2019), dan Gel Tabir Surya (Rejeki \& Wahyuningsih, 2015).

Kelebihan nyamplung sebagai bahan baku energi, yaitu bijinya mengandung kadar oktan cukup tinggi dibandingkan beberapa tanaman penghasil biofuel lainnya. Kandungan minyak pada biji nyamplung sebesar 40-73\%, kusambi (Scleichera oleosa) sebesar 55-70\%, dan jarak pagar (Jatropha curcas) sebesar 40-70\% (Science \& Seminar, 2007). Sebagian besar komponen dari pohon nyamplung dapat menghasilkan minyak, tetapi yang paling banyak kandungannya pada bagian buah dan getah pohon (Prasetyawati \& Mangopang, 2013). Sementara limbah hasil proses pengolahan berupa kulit tempurung dan ampas biji nyamplung dapat digunakan sebagai arang aktif.

Kelurahan Kebondalem sendiri merupakan pemerintahan desa yang cukup bagus dalam menerima program pemberdayaan ekonomi masyarakat, termasuk memanfaatkan biji nyamplung yang banyak tumbuh di daerah ini. Berdasarkan hasil tanya jawab dengan apparat desa Kebondalem, selama ini masyarakat tidak ada yang mengetahui apalagi memanfaatkan biji buah nyamplung yang banyak berada di sepanjang jalan Desa Kebondalem tersebut.

Berdasarkan analisis situasi tersebut, dapat diuraikan beberapa masalah yang dihadapi oleh masyarakat Desa Kebondalem, yaitu: (1) Masih banyak masyarakat yang membutuhkan tambahan penghasilan, apalagi di era pandemi, mereka perlu banyak bekerja di rumah. (2) Belum adanya pengetahuan tentang pemanfaatan biji nyamplung sehingga hanya dibiarkan dan menjadi sampah, (3) perlunya pemahaman pemanfaatan biji nyamplung. (4) tidak adanya alatalat yang memadai untuk pengolahan biji nyamplung menjadi produk yang bermanfaat, khususnya untuk minyak bahan bakar. Diperlukan pengenalan dan pelatihan pemanfaatan biji nyamplung yang selama ini banyak jumlahnya dan menjadi limbah lingkungan menjadi energi bahan bakar.

Tujuan kegiatan pengabdian ini adalah mengenalkan kepada masyarakat akan potensi biji nyamplung yang banyak terdapat di daerah tersebut dan bagaimana cara memanfaatkannya.

\section{METODE}

Kegiatan dilakukan dalam beberapa tahap. Pertama, survey lokasi. Sebelum dilakukan kegiatan ini, tim telah melakukan survey tentang persepsi masyarakat sekitar terhadap pohon dan biji nyamplung. Berdasarkan masalah yang dihadapi masyarakat desa Kebondalem, maka masalah utama yang harus diselesaikan adalah memberikan pemahaman bagaimana memanfaatkan biji nyamplung yang sebelumnya menjadi sampah dan dibiarkan berserakan menjadi minyak nyamplung. Mahasiswa Universitas Jember menawarkan kegiatan pengabdian kepada kepala desa yang diperuntukan bagi masyarakat desa Kebondalem, untuk memberikan 
wawasan dan pelatihan pemanfaatan potensi daerah Kebondalem dan sekitarnya yaitu pohon nyamplung menjadi energi yang bisa diproduksi dan digunakan sendiri untuk kebutuhan seharihari. Kepala desa setuju dan bersedia menyiapkan warga dan tempat yang akan digunakan kegiatan, yang ditunjukkan dengan surat Permohonan yang dikirim ke Univeritas Jember.

Tahap kedua pelaksanaan kegiatan yang diadakan dengan 3 acara:

1. Penyampaian materi tentang potensi pohon nyamplung di daerah Kebondalem dan sekitarnya, manfaat dan penggunaannya, cara membuat dan memproduksi, serta potensinya sebagai sumber pendapatan. Kegiatan ini didukung dengan penggunaan LCD proyektor untuk memudahkan masyarakat memahami materi yang disampaikan.

2. Praktek pembuatan minyak. Tim pengabdian telah menyiapkan bahan dan alat pengabdian. Bahan yang diperlukan adalah biji nyamplung yang diperoleh dari pemungutan biji yang sudah jatuh dari pohon di sekitar pohon nyamplung. Adapun alat pengabdian adalah blender yang biasanya digunakan untuk menggiling daging dan alat press yang dibuat oleh mahasiswa Universitas jember.

3. Diskusi dan anya jawab untuk memperdalam materi yang telah disampaikan.

Keberhasilan kegiatan ini bisa dilihat dari bagaimana respon peserta dalam acara ini terhadap materi yang disampaikan baik dari pertanyaan yang muncul, sikap dari peserta setelah mengikuti kegiatan ini, dan jangka panjang tujuan kegiatan ini adalah perubahan ekonomi masyarakat sasaran.

\section{HASIL DAN PEMBAHASAN}

Kegiatan pengabdian ini diawali dengan pembukaan oleh Kepala Desa Kebondalem yang memberikan gambaran tujuan acara ini diadakan. Kepala desa juga berharap dengan kegiatan ini bisa menggerakkan ekonomi masyarakat Desa Kobendalem. Kegiatan ini dilaksanakan di Balai Desa Kebondalem Kecamatan Bangorejo Kabupaten Banyuwangi, seperti ditunjukkan pada Gambar 1. Pada gambar tersebut terlihat bahwa kegiatan dilakukan dengan menerapkan protokol Kesehatan, sehingga tempat duduk berjarak dan semua peserta menggunakan masker.

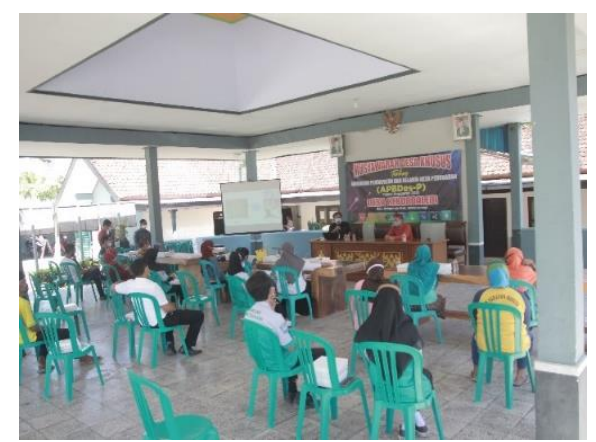

Gambar 1. Pelaksanaan kegiatan

Kegiatan pertama berupa pemaparan materi tentang sejarah awal mula nyamplung sampai di Indonesia, letak geografis daerah dengan potensi pohon nyamplung besar. Manfaat dari nyamplung sendiri juga dipaparkan dengan pembahasan mengarah kepada kelangkaan bahan bakar minyak bumi dan potensi besar dari pohon nyamplung sebagai alternatif pengganti bahan bakar konvensional tersebut. Setelah itu dilanjutkan dengan penjabaran terkait hal aspek ekonomis dari biji nyamplung yang sudah lama ada seperti perusahan di beberapa daerah di Indonesia yang memanfaatkan biji nyamplung menjadi minyak biofuel dan banyak permintaan minyak tersebut hingga sering melakukana ekspor ke manca negara.

Kegiatan kedua adalah adalah praktek proses pembuatan minyak sebagai bahan bakar dari biji nyamplung. Mekanisme dipaparkan secara mendetail karena telah disiapkan bahan contoh yang ditunjukkan, mulai dari biji nyamplung, buah nyamplung dari biji yang sudah dikupas, dan buah yang sudah diblender, seperti ditunjukkan pada Gambr 2. Pada Gambar tersebut biji nyamplung yang akan dibuat minyak harus dalam keadaan kering dan dikupas 
sehingga didapatkan buah nyamplung. Buang nyamlung kemudian diblender sehinga menjadi dimensi kecil seperti ampas kelapa. Buah nyampling berdimensi seperti ini memudahkan untuk melakukan ekstraksi mekanik (press) menjadi minyak nyamplung.

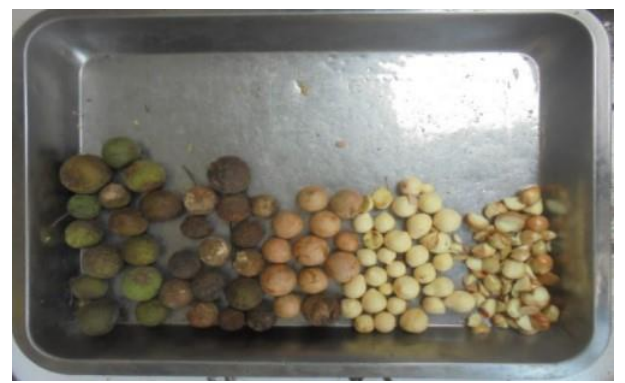

Gambar 2. Buah nyamplung dari hijau hingga siap diekstraksi

Ampas buah nyamplung setelah diblender dibungkus kain kemudian diekstraksi mekanik menggunakan alat press seperti ditunjukkan pada Gambar 3. Kain berfungsi sebagai filter agar ampas nyamplung tidak bercampur dengan minyak yang dihasilkan. Ekstraksi dilakukan beberapa kali untuk memberikan kesempatan terjadinya minyak nyamplung. Dari 1 kg buah nyamplung dihasilkan sekitar $300 \mathrm{ml}$ minyak nyamplung. Hasil ekstraksi menghasilkan minyak nyamplung ditunjukkan pada Gambar 4.

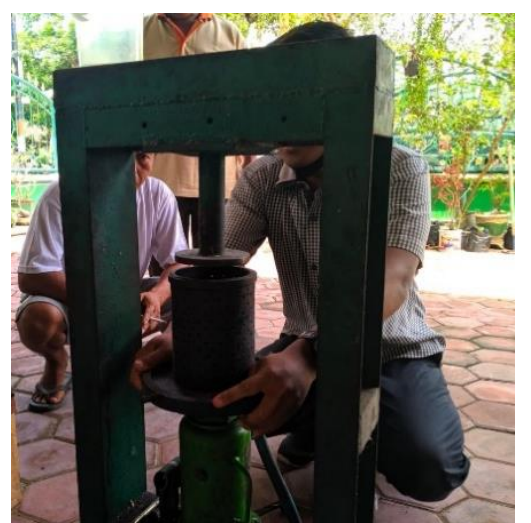

Gambar 3. Proses ekstraksi biji nyamplung

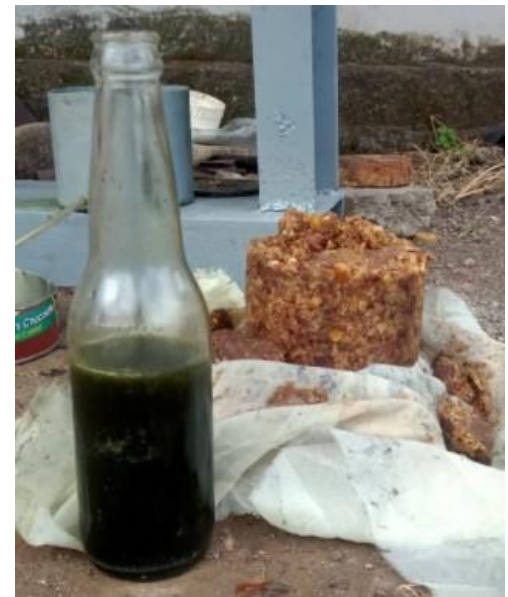

Gambar 4. Hasil minyak nyamplung

Semua proses pembuatan minyak nyamplung ini diperagakan oleh mahasiswa. Peserta juga diperlihatkan bagaimana hasil dari minyak yang dihasilkan dari proses tersebut. Minyak nyamplung yang dihasilkan bisa digunakan sebagai bahan bakar kompor minyak. Jika minyak nyamplung diproses lebih lanjut dengan beberapa tahapan, bisa menghasilkan biodiesel. Ini 
proses berikutny yang perlu dilakukan jika masyarakat sudah mulai menyadari pentingnya biji minyamplung ini.

Berdasarkan hasil sosialisasi yang diadakan, semua peserta nampak antuasias dari penyampaian materi potensi biji nyamplung, yang diindikasikan dengan pertanyaan yang disampaikan. Beberapa pertanyaan yang muncul terkait bagaimana masyarakat bisa mendapatkan alat-alat yang digunakan untuk memproduksi minyak nyamplung dan berapa harga jual minyak nyamplung, karena peserta optimis jika ada alat yang digunakan mereka mampu membuat minyak nyamplung sendiri. Tim pengabdian menyampaikan, harga umum di pasaran online yang ada didaerah lain. Tapi saat tim pengabdian masih melakukan penelitian tentang randemen minyak nyamplung ini dan kualitas minyak nyamplung yang dihasilkan sehingga belum bisa memberikan harga jual minyak yang dihasilkan masyarakat Kebondalem karena masih harus diketahui kualitasnya dan dibandingkan dengan kualitas minyak nyamplung dari daerah lain. Sebagai tindaklanjut kegiatan ini, masyarakat bersedia menyiapkan bahan berupa biji nyamplung sebagai bahan penelitian bagi tim pengabdian dan akan dibeli dengan harga yang pantas untuk dilakukan penelitian lebih lanjut. Harga ini akan disesuaikan jika hasil penelitian telah diketahui kualitas minyak nyamplung yang dihasilkan.

\section{KESIMPULAN}

Peserta pengabdian mendapatkan ilmu baru bagaimana potensi yang besar di sekitarnya bisa diproses dengan mudah menjadi minyak yang bisa digunakan sendiri maupun menjadi barang yang layak dijual secara luas. Secara umum masyarakat mudah apabila dibimbing dalam memberdayakan potensi yang ada di daerahnya. Melihat antusiasme peserta, perlu dilakukan kegiatan tindak lanjut untuk mengawal potensi ini hingga mampu membentuk masyarakat yang mandiri ekonomi dan energi.

\section{UCAPAN TERIMA KASIH}

Penulis mengucapkan terima kasih kepada Kepala Desan Kebondalem Kecamatan Bangorejo Kabupaten Banyuwangi yang telah memberikan dukungan penuh dengan menyediakan tempat dan mengundang warga Desa Kebondalem untuk mengikuti acara ini.

\section{DAFTAR PUSTAKA}

Araujo, 2010. (2017). Инновационные подходы к обеспечению качества в здравоохраненииNo Title. Вестник Росздравнадзора, 6, 5-9.

Banyuwangi, B. K. (2017). Badan pusat statistik kabupaten banyuwangi.

Bu KU Pe G a N G a N. (n.d.).

Handayani, S. S., Gunawan, E. R., Suhendra, D., Murniati, M., \& Aditha, I. M. (2020). Karakterisasi Sifat Fisiko Kimia Minyak Nyamplung Sebagai Bahan Baku Sabun Padat Transparan. Jurnal Pijar Mipa, 15(4), 411. https://doi.org/10.29303/jpm.v15i4.1328

Industri, F. T. (2015). ( Callophylum inophyllum ) Dengan Proses Extraction Biodiesel Production from Nyamplung seed ( CALLOPHYLUM INOPHYLLUM) using liquid-liquid extraction and process with cuttlefish shell's catalisyst.

Prasetyawati, C. A., \& Mangopang, A. D. (2013). Konservasi Kawasan Pesisir dengan Tanaman Nyamplung. Jurnal Eboni, 10(1), 14-25. http://ejournal.forda-mof.org/ejournallitbang/index.php/buleboni/article/view/5001

Rakhmawati, R., Artanti, A. N., \& Afifah, N. (2019). Pengaruh Variasi Konsentrasi Tamanu Oil terhadap Uji Stabilitas Fisik Sediaan Body Lotion. Annual Pharmacy Conference, 4(1), 53-65.

Rejeki, S., \& Wahyuningsih, S. S. (2015). Formulasi Gel Tabir Surya Minyak Nyamplung (Tamanu Oil) Dan Uji Nilai SPF Secara In Vitro. Jurnal Farmasi, 97-103. 
Science, A., \& Seminar, T. (2007). Future Biodiesel Research Asian Science and Technology Seminar. Engineering and Technology, March.

Susila, I. W. W. (2018). Nyamplung Tanaman Multifungsi Potensi Sebaran Dan Manfaatnya Di Nusa Tenggara Barat Dan Bali. 1-77. 